\title{
Collection and Culture of Human Connective Tissue Cells from Gingival Explant Technique for Oral Tissue Bioengineering
}

\author{
Colección de Células de Tejido Conectivo Humano a Partir de la \\ Técnica de Explante Gingival para Bioingeniería de Tejidos Orales
}

\author{
Fernando Antônio Mauad de Abreu ${ }^{1,2}$; Igor Daniel Garcia Reis ${ }^{1}$; Gerluza Aparecida Borges Silva ${ }^{1}$ \& Erika Cristina Jorge ${ }^{1}$
}

ABREU, F. A. M.; REIS, I. D. G.; SILVA, G. A. B. \& JORGE, E. C. Collection and culture of human connective tissue cells from gingival explant technique for oral tissue bioengineering. Int. J. Morphol., 37(4):1229-1233, 2019.

SUMMARY: Cell culture is an important tool in medical, odontological and biological research laboratories, supporting cell therapies and tissue bioengineering strategies. Gingival fibroblasts present structural function, being able to modulate their metabolic capacity, which is reflected in the tissue morphology. The possibility of culturing fibroblasts in vitro, in monolayer or on three-dimensional scaffolds, for subsequent transplants in vivo opens important perspectives for the periodontal surgical clinic. The objective of the present article is to present a method of obtaining and cultivating viable human gingival fibroblasts for in vitro research. Explants derived from periodontal surgical discards were used, grown in $25 \mathrm{~cm}^{2}$ bottles to obtain a primary cell culture. After observing the proliferation and growth of the fibroblasts that interconnected and formed a monolayer network, involving the periphery of the explants, it was possible to remove the explants, to make the passage and the new subcultures were obtained in a ratio of 1:1. After 7 days, the amount of viable cells was analyzed in triplicate, using the Neubauer chamber technique, in cell culture bottles of $25 \mathrm{~mm}^{2}$ (T25) and $75 \mathrm{~mm}^{2}$ (T75). Fibroblasts were described and subclassified morphologically. The results showed a growth pattern in both bottles, but with a larger number in bottles of $75 \mathrm{~cm}^{2} . \mathrm{Cells}^{\mathrm{s}}$ with fibroblastic morphology were subclassified into reticular and fusiform, being predominant those with fusiform morphology. In conclusion, culture of explant of human gingival connective tissue is a viable method for obtaining gingival connective tissue cells suitable for laboratory tests in cell culture, aiming at obtaining constructs for gingival tissue engineering.

KEY WORDS: Cell culture technique; Primary cell culture; Connective tissue Cells; Cellular biology.

\section{INTRODUCTION}

Cells are a one of the cornerstones of tissue bioengineering, and their use may provide an autologous supply of tissues for the restoration of lost structures, which is particularly relevant for an aging population where the potential for tissue repair is limited (Cheung et al., 2014). Nonetheless, keratinized gingival loss and gingival recession are common clinical occurrences and observed in a number of patient populations, regardless of age and ethnicity. Several factors were related to the etiology of oral tissue loss, such as periodontal disease, traumatic brushing, oral piercing, orthodontic treatment sequelae, among others. The regeneration of the structure and function of the oral epithelium is one of the main objectives in maintaining oral and periodontal health (Maroso et al., 2015).

Tissue bioengineering represents a strategy to overcome the difficulties encountered in the various methods of periodontal treatment, such as mucogingival surgeries with soft tissue sections of the oral cavity, limited amount of keratinized gingival tissue in donor sites for grafts and second-degree scarring with marked symptomatology (Golinski et al., 2011). Human gingival fibroblasts are involved in the repair of gingival connective tissue and in the mediation of epithelial cell morphogenesis, also aiding in the restoration of oral epithelium (Mussig et al., 2008; Locke et al., 2008).

The main cells of gingival connective tissue are fibroblasts. Traditionally, fibroblasts cells were considered as a static population of spindle cells, which maintain and sustain epithelial tissue through the secretion and degradation of extracellular collagen matrix. Currently, fibroblasts play an active and important role in almost all coating fabric processes, and its involvement in various pathophysiological conditions, including, healing, repair, aging, psoriasis, cancer among others, is only beginning to be understood (Sriram et al., 2015).

\footnotetext{
${ }^{1}$ Laboratory of Oral and Development Biology, Department of Morphology, Biological Sciences Institute, UFMG - Federal University of Minas Gerais, Belo Horizonte, MG, Brazil.

${ }^{2}$ Laboratory of Oral Biology, Department of Odontology, PUCMG - Pontifical Catholic University of Minas Gerais, Belo Horizonte, MG, Brazil.
} 
Advances in research methods involving cell culture techniques, in a multidisciplinary way, point to the clinical possibility of producing and replacing lost tissues, besides replacing some animal models, presenting itself as a viable methodological alternative for the development of new technologies. In this context, the present article intends to describe a method for obtaining and cultivating human gingival fibroblasts, by explants derived from surgical discards, for in vitro research.

\section{MATERIAL AND METHOD}

Collection of biological samples. Samples were collected from surgical discards from periodontal surgical procedures, such as connective graft donor areas of adult individuals. The Research Ethics Committee of UFMG, under registry number CAAE 42372815.3.0000.5149, previously approved all clinical and experimental procedures.

Immediately after removal of surgical discards, the gingival fragments were washed $2 \mathrm{x}$ with PBS buffered saline $\left(0.2 \mathrm{~mL} / \mathrm{cm}^{2}\right)$ plus $1 \%$ Gentamicin Sulfate $60 \mathrm{mg}$ (SG). Subsequently, all the visible epithelial and adipose tissue was removed with a surgical blade number $15 \mathrm{C}$ inserted in number 3 scalpel cable over sterile $60 \mathrm{~mm}$ diameter Petri dishes. The samples were then stored in $5 \mathrm{~mL}$ of Dulbecco's Modified Eagle Medium and Nutrient Mixture F-12 (DMEM / F-12, powder-Life Technologies / cod.12500-062 Gibco ${ }^{\circledR}$ ) at $4{ }^{\circ} \mathrm{C}$ for a maximum of 4 hours, until they were sent to the research laboratory for processing.

Obtaining human connective tissue cells from gingival explants. Within the laminar flow, in a sterile environment, the gingival connective tissue samples were fragmented at approximately $2 \mathrm{~mm}^{2}$, using sterile scissors and scalpel blades. $25 \mathrm{~cm}^{2}$ (T25) culture flasks were pre incubated at 37 $\mathrm{oC}$ in $5 \% \mathrm{CO}_{2}$ humidified atmosphere containing $1 \mathrm{~mL}$ of DMEM / F-12 supplemented with $10 \%$ fetal bovine serum and $1 \%$ gentamicin sulfate $60 \mathrm{mg}$ in $50 \mu \mathrm{g} / \mathrm{mL}$ (DMEM / F12 complete), for 30 minutes, forming a film, to equilibrate the gas phase. The explants were then added to the bottles, at most three samples per bottle. In the incubator, at $37^{\circ} \mathrm{C}$, $5 \% \mathrm{CO}_{2}$, the bottles were positioned inverted and thus remained for 30 minutes, for initial adherence of the explants to the substrate. Subsequently, the bottles were placed in the original position, followed by the addition of $2 \mathrm{~mL}$ of complete DMEM / F-12 medium, enough to leave all the biological material submerged in the culture medium. The culture medium was changed every 24 hours by replacing only half the contents of the culture bottles, i.e. $1.5 \mathrm{ml}$ of fresh culture medium. The cell growth was evaluated daily for 14 days until $80 \%$ confluency was reached and the passages were initiated by means of trypsinization and obtaining a population of viable fibroblasts cells, and the monitoring was performed by inverted phase microscopy (objective 40x at 200x, Trinocular Inverted Motic AE 31 with Moticam 2300-Canada CCD camera). Enzymatic digestion does not been necessary for gingival connective tissue cell isolation.

Standardization of the initial population of gingival connective tissue cells. After cell sub confluence of approximately $80 \%$, the cells were trypsinized to obtain a new subculture in a ratio of $1: 1$. In that first passage, the explants were removed. For the trypsinization process, the culture medium was removed and the cells washed 2 times with PBS $\left(0.2 \mathrm{~mL} / \mathrm{cm}^{2}\right)$ and withdrawn from the substrate by the action of trypsin $(0.25 \%, 2 \mathrm{~mL})$, for up to 3 min to $37^{\circ} \mathrm{C}$. Inactivation of trypsin was performed by the addition of $4 \mathrm{~mL}$ of complete culture medium. The cells were then centrifuged at $1500 \mathrm{rpm} / 350 \mathrm{~g}$, resuspended in complete DMEM/F-12 culture medium and transferred to two bottles. After a further sub confluence of approximately $80 \%$, the cells were again trypsinized and $20 \%$ of their final volume was transferred to the new T25 bottles to promote a viable gingival connective tissue cells culture. The culture medium was changed every 48 hours by replacing only half the contents of the culture bottles, i.e. $2.5 \mathrm{~mL}$ of fresh complete DMEM/F-12 culture medium.

Obtaining viable cells for experiments. After $80 \%$ cell confluency, the entire DMEM/F-12 culture medium was removed and replaced with $4 \mathrm{~mL}$ of the DMEM/F-12 culture medium. After an incubation period of $2 \mathrm{~h}$ at $37^{\circ} \mathrm{C}$, the cells were trypsinized, centrifuged and resuspended, as previously described. Thereafter, an aliquot of $50 \mathrm{~mL}$ of culture medium was used for counting the cells. Trypan blue $(0.4 \%$ solution in PBS) was added in the microtube to the ratio of $1: 1$. This ratio is necessary to determine the sample dilution factor. Counts were performed in Neubauer chambers. Blue stained cells represent dead cells, while cells that were not stained represent viable cells. Cell viability should remain above $90 \%$ (Helbig \& Speit, 1997) so that the proposed preliminary culture protocol can be accepted and the experiment proceeded. For the experiments, 3 bottles $25 \mathrm{~mm}^{2}$ (T25) and 3 bottles of $75 \mathrm{~mm}^{2}$ (T75) were used to evaluate the quantity and describe the morphology of the obtained cells.

Statistical analyses. For proliferation experiment assay, the statistical analysis used was T student test, using GraphPad Prism 6 software (GraphPad, San Diego, CA, USA).Data are represented as mean and standard deviation, were evaluated three times, and results were considered significant when $\mathrm{p}<0.05$. 


\section{RESULTS}

Cell migration from the explant to the culture bottle. Before the confluence of $80 \%$ for the first passage, proliferation and migration of gingival colored tissue cells from the explants were evaluated by light microscopy in 24 h, 3, 5, 10 and 14 days. In $24 \mathrm{~h}$ of culture the red eyebrows of the gingival connective tissue were observed (Fig. 1A). On the third day of culture, we observe the first fibroblastic cells and some residual red blood cells (Fig. 1B). At 5 days, a larger number of fibroblasts were observed that interconnected forming a network (Fig. 1C). At 10 days the cells occupy the periphery of the explant of gingival tissue and are juxtaposed forming a cellular monolayer (Fig. 1D). At 14 days, the fibroblast cells were more juxtapose and intimidate the contact suggesting a cellular overlay. Outside the explant area, cell growth is visible with a region of the plate occupied by juxtaposed (closer to explant) and crosslinked (farther from explant) cells and the entire cultivation area of T25 bottle (Figs. 1E and 1F).

Morphological analysis of the connective tissue cells from explants. After the first passage, the cells had fibroblastic morphology and were separated into two groups: reticular (Figs. 2A-C) and fusiform (Figs. 2D-F), mostly interconnected by cytoplasmic extensions until their juxtaposition and definition of the monolayer.
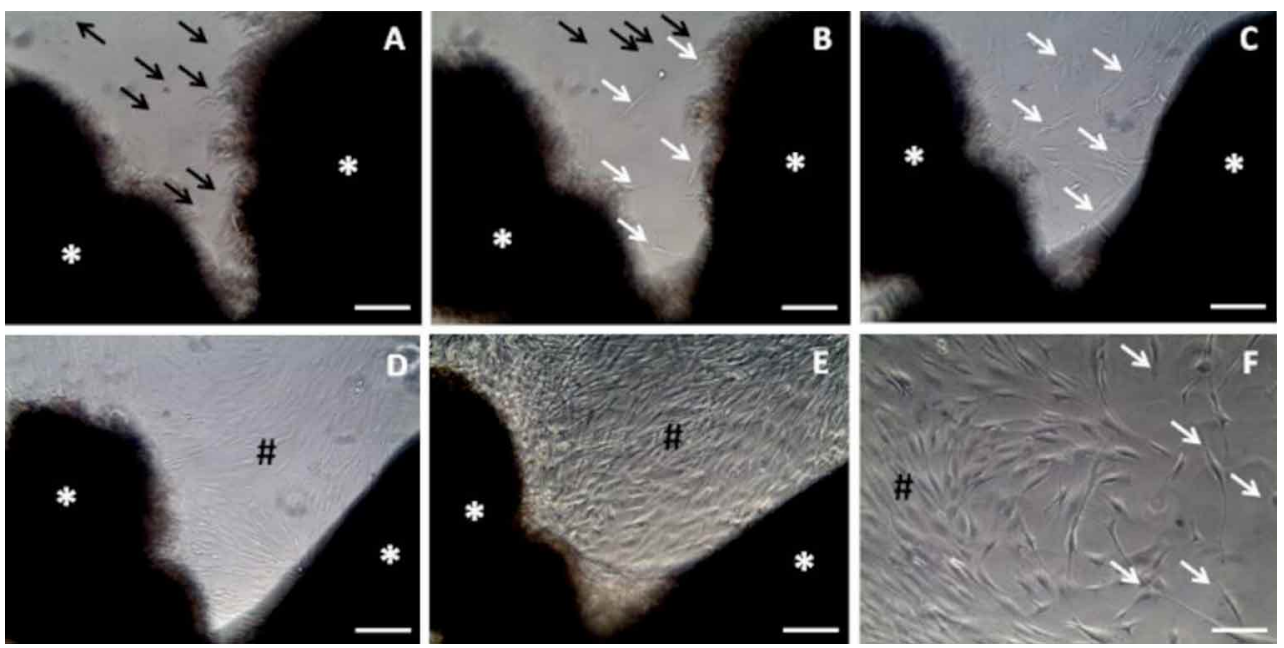

Fig. 1. Temporal evolution of explant culture of human gingival connective tissue. $24 \mathrm{~h}$ (A), 3 days (B), 5 days (C), 10 days (D) and 14 days (E, F). Fibroblasts derived from the explant in migration and expansion (F). Red blood cells was observed in the first days of culture (black arrows), fibroblasts (white arrows) and cell monolayer (\#) on the periphery of the explant (*). A-E Bars: $200 \mathrm{~mm}$; F: $80 \mathrm{~mm}$.
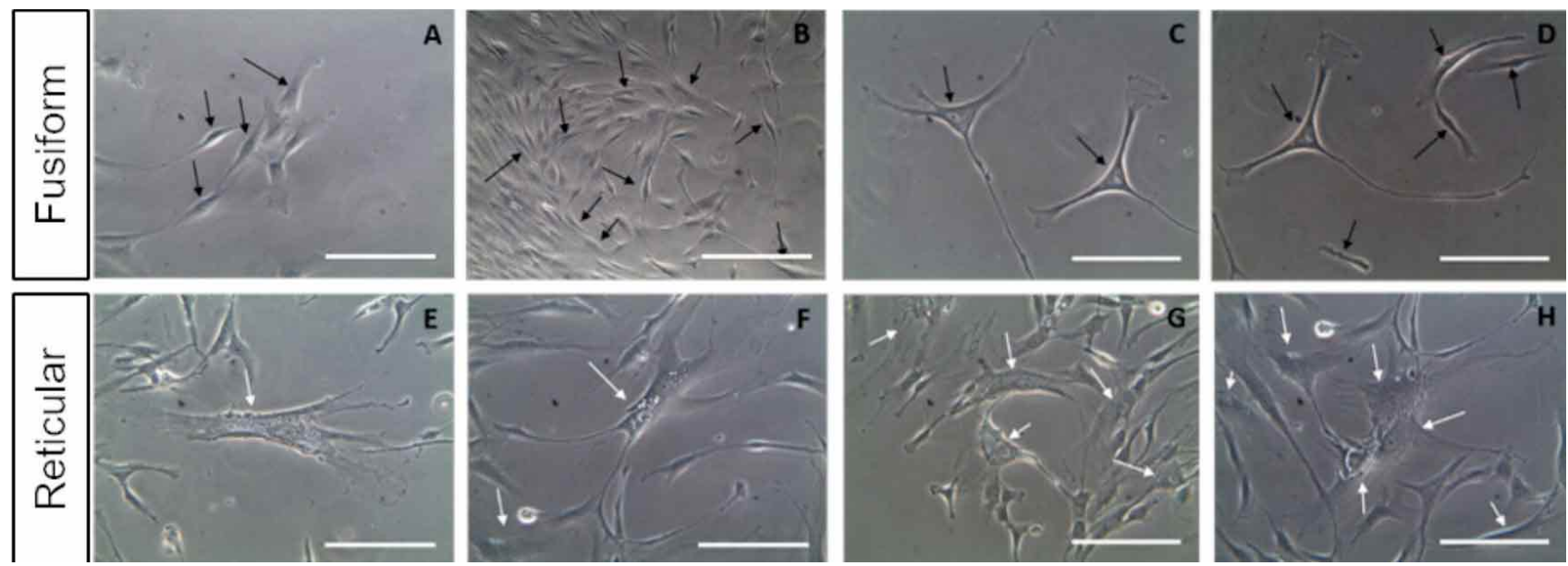

Fig. 2. Morphology of the fibroblastoid cell subtypes: fusiform (A-D; black arrows) and reticular (E-H; white arrows). Bars A, C-G: 40 mm. Bar B: 80 mm. 
Cell proliferation. The counts performed in Neubauer chambers of T25 and T75 bottles were performed in triplicates, where blue stained cells represent dead cells, while cells that were not stained represent viable cells. A significant difference in cell proliferation was observed when compared to the T25 culture bottle for T75 (Fig. 3).

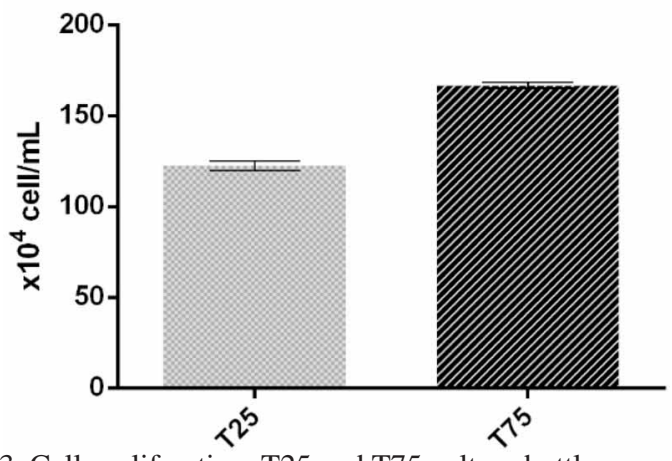

Fig. 3. Cell proliferation. T25 and T75 culture bottle.

\section{DISCUSSION}

Surgical discards from gingivectomy, connective graft donor area or third molar extraction from adult individuals with periodontal health were used in this protocol. This method of obtaining cells in primary cultures of human gingival fibroblasts was described in the studies of Hillmann et al. (2002) and Golinski et al. Cultured fibroblasts are characterized by their morphology, cell growth and adhesion on plastics, expression of markers such as Vimentin and Type I collagen, and lack of expression of markers related to other specific cell lines (Sriram et al.). Human gingival fibroblasts (FGH) can be obtained from immortalized cell collections such as the American Type Culture Collection (HGF-1, ATCC-CRL-2014) (Bao et al., 2014). In addition, the literature also reports various forms of biopsies or surgical discarding of human patients (Zurek et al., 2015). In order to perform the concept of gingival tissue engineering, it is interesting to obtain gingival connective tissue cells, as recommended by the present study.

The diversity of the fibroblast cell population of the adult organism exhibits a functional diversity, which was formed at several levels, beginning with the embryonic origin of the cell population, to the microenvironment of tissue residence. In humans, the papillary and reticular dermis consists of two populations in distinct fibroblasts and suggests that the fibroblasts of the papillary dermis with aging may differentiate into phenotype fibroblasts of the reticular dermis (Sriram et al.). For fibroblasts derived from the buccal mucosa, in patients with Oral Fibrosis Submucosa,
Mathew et al. (2011) classified seven subtypes between fusiform and reticular morphologies. In the present work, we found fibroblast moforlogies that were divided into fusiform and reticular. For a better classification of fibroblast cell populations derived from gingival connective tissue, further studies will be needed defining specific markers for each cell group.

The cells in culture undergo a phenomenon that is known by inhibition of contact, because when a cell contacts around them with another cell and forms a monolayer, the mitotic process is inhibited (Alberts et al., 2017). According to Freshney (2000), cell lines with few passages are unstable and require a period of adaptation in cultures and in the case of human gingival fibroblasts, these cultures become stable and rationally consistent, being viable up to the $35^{\text {th }}$ passage. Huang et al. (2002) chose cells from the $5^{\text {th }}$ to $7^{\text {th }}$ passage to evaluate the cytotoxicity of orthodontic adhesive cements on gingival fibroblasts, whereas for the same purpose, Tang et al. (1999) used 6th passage cells. In this work, cells from the 2nd passage were evaluated for viability by Trypan blue, during counting by the Neubauer chamber method, demonstrating a cell viability above $90 \%$, in agreement with Helbig \& Speit and allowing the proposed preliminary culture protocol can be accepted for cellular experiments. The difference in proliferation between the T25 and T75 bottles can be explained by the larger area and be colonized in the $75 \mathrm{~mm}^{2}$ flange, a larger space means a smaller possibility of premature contact of one cell with another cell, delaying the inhibition of the mitotic process as described. In conclusion, the collection and culture of human gingival connective tissue cells, using explants derived from dental surgical discards, is a viable, simple method with low costs and adequate performance for in vitro research.

ABREU, F. A. M.; REIS, I. D. G.; SILVA, G. A. B. \& JORGE, E. C. Colección y cultivo de células de tejido conectivo humano a partir de la técnica de explante gingival para bioingeniería de tejidos orales. Int. J. Morphol., 37(4):1229-1233, 2019.

RESUMEN: El cultivo celular es una herramienta importante en los laboratorios de investigación médica, odontológica y biológica, que apoyan las terapias celulares y las estrategias de bioingeniería de tejidos. Los fibroblastos gingivales presentan una función estructural, pudiendo modular su capacidad metabólica, que se refleja en la morfología tisular. La posibilidad de cultivar fibroblastos in vitro, en monocapa o en andamios tridimensionales, para trasplantes posteriores in vivo abre perspectivas importantes para la clínica de cirugía periodontal. El objetivo del presente artículo es presentar un método para obtener y cultivar fibroblastos gingivales humanos viables para investigación in vitro. Se utilizaron explantes derivados de los descartes quirúrgicos periodontales, crecidos en frascos de $25 \mathrm{~cm}^{2}$ para obtener un cultivo de células primarias. Después de observar la proliferación y el crecimiento 
de los fibroblastos que se interconectaron y formaron una red de monocapa, que involucraba la periferia de los explantes, fue posible eliminar los explantes, hacer el pasaje y los nuevos subcultivos se obtuvieron en una proporción de 1:1. Después de 7 días, la cantidad de células viables se analizó por triplicado, utilizando la técnica de cámara de Neubauer, en botellas de cultivo celular de 25 $\mathrm{mm}^{2}$ (T25) y $75 \mathrm{~mm}^{2}$ (T75). Los fibroblastos fueron descritos y sub-clasificados morfológicamente. Los resultados mostraron un patrón de crecimiento en ambas botellas, pero con un número mayor en botellas de $75 \mathrm{~cm}^{2}$. Las células con morfología fibroblástica se subclasificaron en reticulares y fusiformes, predominando aquellas con morfología fusiforme. En conclusión, el cultivo de explante de tejido conectivo gingival humano es un método viable para obtener células de tejido conectivo gingival adecuadas para pruebas de laboratorio en cultivos celulares, con el objetivo de obtener construcciones para la ingeniería del tejido gingival.

PALABRAS CLAVE: Técnica de cultivo celular; Cultivo celular primario; Células conectivas del tejido; Biología celular.

\section{REFERENCES}

Alberts, B.; Johnson, A.; Lewis, J.; Raff, M.; Roberts, K. \& Walter, P. Molecular Biology of the Cell. $7^{\text {th }}$ ed., Garland Science, 2017.

Bao, K.; Akguel, B. \& Bostanci, N. Establishment and characterization of immortalized gingival epithelial and fibroblastic cell lines for the development of organotypic cultures. Cells Tissues Organs, 199(4):22837, 2014.

Cheung, J. W.; McCulloch, C. A. \& Santerre, J. P. Establishing a gingival fibroblast phenotype in a perfused degradable polyurethane scaffold: mediation by TGF-b1, FGF-2, b1-integrin, and focal adhesion kinase. Biomaterials, 35(38):10025-32, 2014.

Freshney, R. I. Culture of Animal Cells. A Manual of Basic Technique. $4^{\text {th }}$ ed. New York, Wiley, 2000.

Golinski, P. A.; Gröger, S.; Herrmann, J. M.; Bernd, A. \& Meyle, J. Oral mucosa model based on a collagen-elastin matrix. J. Periodontal Res., 46(6):704-11, 2011.

Helbig, R. \& Speit, G. DNA effects in repair-deficient V79 Chinese hamster cells studied with the comet assay. Mutat. Res., 377(2):279-86, 1997.

Hillmann, G.; Steinkamp-Zucht, A.; Geurtsen. W.; Gross, G. \& Hoffmann, A. Culture of primary human gingival fibroblasts on biodegradable membranes. Biomaterials, 23(6):1461-9, 2002.

Huang, T. H.; Tsai, C. Y.; Chen, S. L. \& Kao, C. T. An evaluation of the cytotoxic effects of orthodontic bonding adhesives upon a primary human oral gingival fibroblast culture and a permanent, human oral cancer-cell line. J. Biomed. Mater. Res., 63(6):814-21, 2002.

Locke, M.; Hyland, P. L.; Irwin, C. R. \& Mackenzie, I. C. Modulation of gingival epithelial phenotypes by interactions with regionally defined populations of fibroblasts. J. Periodontal. Res., 43(3):279-89, 2008.

Maroso, F. B.; Gaio, E. J.; Rösing, C. K. \& Fernandes, M. I. Correlation between gingival thickness and gingival recession in humans. Acta Odontol. Latinoam., 28(2):162-6, 2015.

Mathew, D. G.; Skariah, K. S. \& Ranganathan, K. Proliferative and morphologic characterization of buccal mucosal fibroblasts in areca nut chewers: a cell culture study. Indian J. Dent. Res., 22(6):879, 2011.

Mussig, E.; Steinberg, T.; Schulz, S.; Spatz, J. P.; Ulmer, J.; Grabe, N.; Kohl, A.; Komposch, G. \& Tomakidi, P. Connective-tissue fibroblasts established on micropillar interfaces are pivotal for epithelial-tissue morphogenesis. Adv. Funct. Mater, 18(19):2919-29, 2008.
Sriram, G.; Bigliardi, P. L. \& Bigliardi-Qi, M. Fibroblast heterogeneity and its implications for engineering organotypic skin models in vitro. Eur. J. Cell Biol., 94(11):483-512, 2015.

Tang, A. T.; Liu, Y.; Björkman, L. \& Ekstrand, J. In vitro cytotoxicity of orthodontic bonding resins on human oral fibroblasts. Am. J. Orthod. Dentofacial Orthop., 116(2):132-38, 1999.

Zurek, J.; Dominiak, M.; Botzenhart, U. \& Bednarz, W. The use of a biostatic fascia lata thigh allograft as a scaffold for autologous human culture of fibroblasts--An in vitro study. Ann. Anat., 199:104-8, 2015.

\author{
Corresponding author: \\ Dr. Fernando A. Mauad de Abreu \\ Avenida Dom José Gaspar \\ 500 Coração Eucarístico \\ CEP: 30535-901 - Belo Horizonte \\ Minas Gerais \\ BRAZIL
}

Email: fmauadabreu@gmail.com.br

Received: 30-12-2018

Accepted: 03-06-2019 